\title{
A simulation of the Kuroko type mineralization in Japan
}

\author{
YOSHIMICHI KAJIWARA \\ Geological and mineralogical Institute, Faculty of \\ Science, Tokyo Kyoiku University, Tokyo 112, Japan
}

(Received September 30, 1972; in revised form March 14, 1973)

\begin{abstract}
On the basis of a model chloride-complex solution with the same metallic abundances as the present-day oceanic water, the physicochemical factors controlling the ore-zoning observed in the Kuroko type mineralization in Japan have been examined. The result reveals that the ore-zoning can be explained by the oxidation and/or neutralization processes of the model ore-forming solution. This is in complete harmony with the interpretation expressed in the recent sulfur isotope studies of this type of mineralization. The hypothesis that the Kuroko ore-forming solution might have been derived essentially from the coeval seawater (KAJIWARA, 1973) appears to be acceptable. Extending the hypothesis, it is suggested that many of the hydrothermal systems in the earth's crust probably represent the circulating coeval seawaters. With this view, the natural hydrothermal mineralizations may be divided into two types, (A) mineralizations due to the reduction processes of the incorporated seawater and (B) those due to the oxidation processes of the once reduced circulating seawater. The deposits formed in shallow environments such as Kuroko and those formed in relatively deep environments such as contact metasomatic deposits may represent the oxidation- and the reduction-type mineralizations, respectively.

It is also probable that the generation of silicate magmas in the orogenic belts is closely related to the availability of such circulating seawater in the earth's crust and possibly in the upper mantle.
\end{abstract}

\section{INTRODUCTION}

In the previous paper (KAJIWARA, 1973), the author has demonstrated from available mineralogical and geochemical data that the ore-forming solution responsible for the deposition of "black ore" of the Kuroko type mineralization in Japan is approximately equivalent in chemical composition to the present-day oceanic water, and has suggested from this result and the idea expressed in recent stable isotope studies on this type of mineralization (which have been referred in the previous paper) that the Kuroko ore-forming solution might have been derived essentially from the coeval seawater. To test this hypothesis, in the present paper, the author examines whether it is possible to explain the ore-zoning observed in this type of mineralization in terms 
of a simulation based on a model chloride-complex solution with the same metallic abundances as the present-day oceanic water. (The ore-zoning of the Kuroko type mineralization has been reviewed briefly in the previous paper. For further information, refer to "Volcanism and ore genesis" edited by T. TATsumI, 1970.)

\section{Simulation of the Kuroko Mineralization}

Basic assumptions On the basis of conclusion of the previous paper (KAJIWARA, 1973), the Kuroko type mineralization is simulated on the following fundamental assumptions:

1) The metallic abundances in the ore-forming solution are the same as those observed in the present-day oceanic water. (The data for the oceanic water are taken from Mason (1958).)

2) Chloride complexes are the only important complexes in the ore-forming solution.

3) The system is thermodynamically open to gaseous components.

4) The $\mathrm{pH}$ of the ore-forming solution may vary during the mineralization processes.

5) The metallic abundances in the ore-forming solution remain almost constant throughout all the stages of mineralization.

Genetical conditions of Kuroko ores Combining the above-mentioned assumptions and the thermochemical data given by HeLGESON (1969), an attempt is made to estimate physicochemical factors controlling the deposition of various representative ores of the Kuroko type deposits from this model hydrothermal system.

Black ore Sphalerite, galena, barite, chalcopyrite, and pyrite are the principal mineral constituents of "black ore" in the Kuroko type deposits. Preliminary calculations indicate that all of these minerals would not be coprecipitated in a strict sense from a solution with the same metallic abundances as the present-day oceanic water. Therefore, the mineralization of this type of ore in the model hydrothermal system is examined by somewhat complicated procedures as follows:

1) Limitation of oxygen fugacity on the basis of the coprecipitation of barite and galena (or barite and sphalerite) in the model system. (The concentrations of related metals are taken to be the same as in sea water.)

2) Limitation of sulfur fugacity on the basis of the stability field of pyrite and chalcopyrite at the fixed oxygen fugacity as defined above.

3) Limitation of $\mathrm{pH}$ at the fixed oxygen and sulfur fugacities as defined above.

4) Estimation of the relative abundances of all the related metals in the solution under the above-derived conditions, and comparison of the result with the seawater values. 
(Oxygen fugacity) Coprecipitation of galena and barite in a given aqueous solution system can be expressed by

$$
\mathrm{BaSO}_{4}+\mathrm{Pb}^{++}+\mathrm{S}^{--} \leftrightharpoons \mathrm{PbS}+\mathrm{Ba}^{++}+\mathrm{SO}_{4}^{--}
$$

and the equilibrium constant for the reaction would be given as the ratio of activity products for the minerals. On the other hand, the oxidation-reduction reaction involving the above ionic sulfur species is expressed by

$$
\mathrm{S}^{--}+2 \mathrm{O}_{2} \leftrightharpoons \mathrm{SO}_{4}^{--} \text {. }
$$

Thus, combining (1) and (2), the following equation is obtained:

$$
\mathrm{BaSO}_{4}+\mathrm{Pb}^{++} \leftrightharpoons \mathrm{PbS}+\mathrm{Ba}^{++}+2 \mathrm{O}_{2} \text {. }
$$

Coprecipitation of sphalerite and barite can also be expressed similarly:

$$
\mathrm{BaSO}_{4}+\mathrm{Zn}^{++} \leftrightharpoons \mathrm{ZnS}+\mathrm{Ba}^{++}+2 \mathrm{O}_{2} \text {. }
$$

The equilibrium constants for the reactions (3) and (4) are available below $300^{\circ} \mathrm{C}$ (Helgeson, 1969). Therefore, it is possible to estimate the oxygen fugacities for the coprecipitation of these pairs in this temperature range, if the activities of related metallic ions are given.

In the present case, the total molalities of the metals in the solution are known, that is, the values for the seawater. The activities of the metallic ions can therefore be determined if the total salinity of the solution and the corresponding stoichiometric activity coefficients for the ionic species (HeLGeson, 1969) are given. In this paper, the stoichiometric activity coefficients for related ionic species are taken conventionally to be those for 1 molal $\mathrm{NaCl}$ solution. Fig. 1 shows the oxygen fugacity values required for the coprecipitation of galena-barite and sphalerite-barite in the model hydrothermal system below $300^{\circ} \mathrm{C}$. It is seen from the diagram that the equilibrium curves for these pairs are satisfactorily consistent with each other and situated well within stability fields of the related minerals. The result is fairly consistent with available mineralogical and geochemical data for "black ore" of the Kuroko type deposits (refer to the previous paper, KaJIWARA, 1973).

(Sulfur fugacity) In Fig.2, the region of sulfur fugacity within which pyrite and chalcopyrite (in addition to sphalerite, galena, and barite) can coexist stably at the fixed oxygen fugacity defined in the foregoing is represented, and some activity curves of FeS are superposed on it. The diagram is constructed on the basis of the following reactions, using HELGESON's (1969) data:

$$
\begin{aligned}
\mathrm{Cu}_{5} \mathrm{FeS}_{4}+4 \mathrm{FeS}_{2} & \leftrightharpoons 5 \mathrm{CuFeS}_{2}+\mathrm{S}_{2}, \\
4 \mathrm{Fe}_{3} \mathrm{O}_{4}+\mathrm{O}_{2} & \leftrightharpoons 6 \mathrm{Fe}_{2} \mathrm{O}_{3}
\end{aligned}
$$



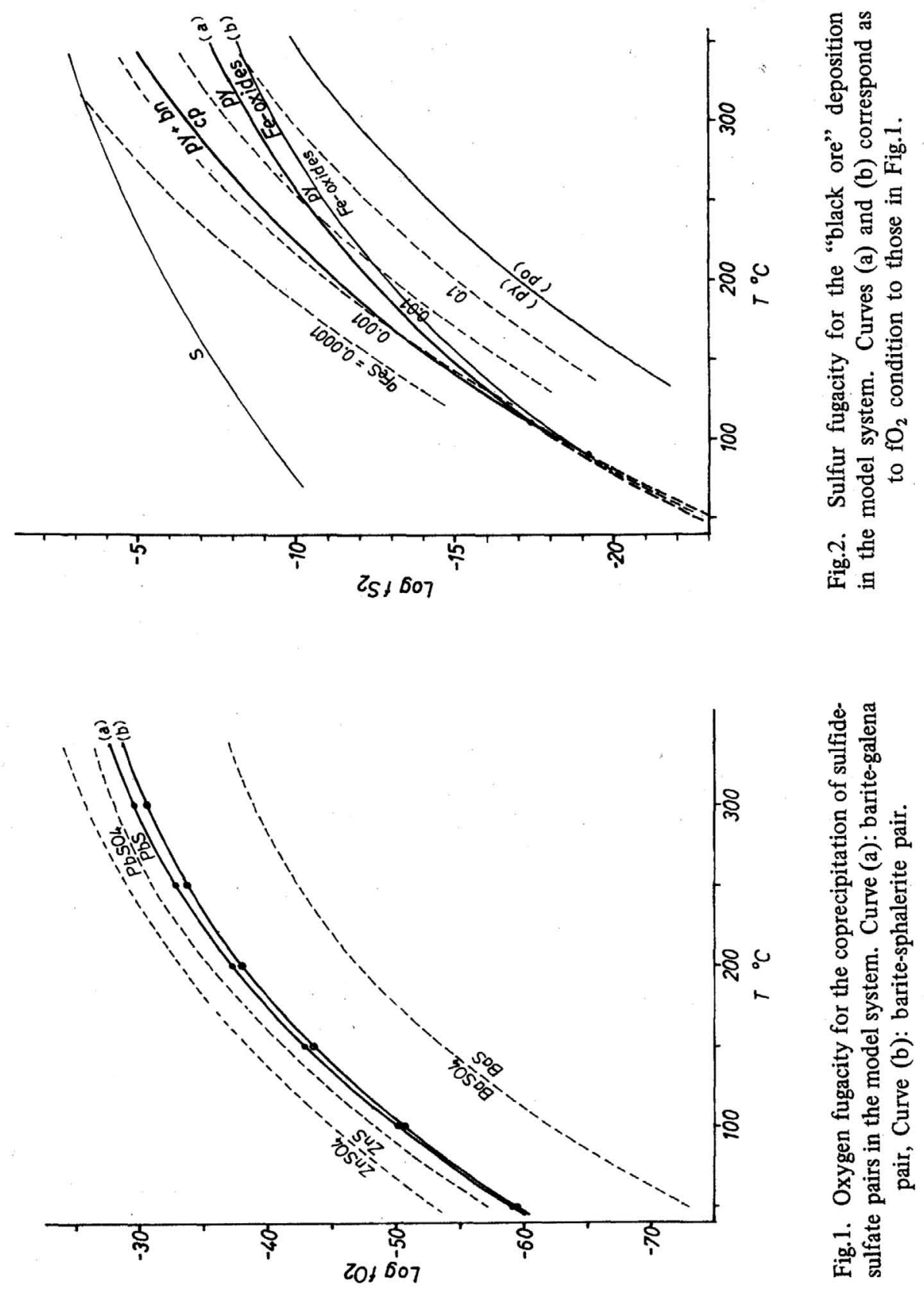


$$
\begin{aligned}
4 \mathrm{FeS}_{2}+3 \mathrm{O}_{2} & \fallingdotseq 2 \mathrm{Fe}_{2} \mathrm{O}_{3}+4 \mathrm{~S}_{2}, \\
3 \mathrm{FeS}_{2}+2 \mathrm{O}_{2} & \leftrightharpoons \mathrm{Fe}_{3} \mathrm{O}_{4}+3 \mathrm{~S}_{2}, \\
2 \mathrm{FeS}+\mathrm{S}_{2} & \Rightarrow 2 \mathrm{FeS}_{2} .
\end{aligned}
$$

It is seen from the diagram that pyrite and chalcopyrite can coexist stably above around $100^{\circ} \mathrm{C}$ and within a very limited region of sulfur fugacity. These temperature and sulfur fagacity conditions are in complete harmony with available mineralogical and geochemical data for "black ore" of the deposits (refer to the previous paper, KAJIWARA, 1973).

(pH) The following reaction is convenient to determine the $\mathrm{pH}$ value responsible for the ore deposition.

$$
4 \mathrm{H}^{+}+2 \mathrm{~S}^{--}+\mathrm{O}_{2} \leftrightharpoons \mathrm{S}_{2}+2 \mathrm{H}_{2} \mathrm{O} \text {. }
$$

The equilibrium constants for the above reaction are available below $300^{\circ} \mathrm{C}$ (HELGESON, 1969). The values of oxygen fugacity and sulfur fugacity have been determined in the foregoing. The activity of $\mathrm{S}^{--}$can be obtained from the activity product of galena (or sphalerite) since the present discussion is based essentially on the coprecipitation of barite and galena (or barite and sphalerite). The activity of water might remain essentially equal to unity in the dilute aqueous solution at $1 \mathrm{~atm}$ confining pressure. Thus, the possible $\mathrm{pH}$ range responsible for the ore deposition can be determined under the given conditions (Fig.3). It is interesting to note that the $\mathrm{pH}$ region defined is fairly close to the curve for neutral water. This result is in agreement with the $\mathrm{pH}$ range of the Kuroko mineralization proposed by KAJIwARA and HONMA (1972).

The $\mathrm{pH}$ of natural hydrothermal systems is generally controlled by silicate mineral equilibria. Let us consider the following reactions involving some common silicate minerals after HELGESON (1969):

$$
\begin{aligned}
3(\mathrm{~F})+2 \mathrm{H}^{+} & \leftrightharpoons(\mathrm{M})+6(\mathrm{Q})+2 \mathrm{~K}^{+} \\
2(\mathrm{M})+2 \mathrm{H}^{+}+3 \mathrm{H}_{2} \mathrm{O} & \leftrightharpoons 3(\mathrm{~K})+2 \mathrm{~K}^{+} \\
2(\mathrm{Ab})+2 \mathrm{H}^{+}+\mathrm{H}_{2} \mathrm{O} & \leftrightharpoons(\mathrm{K})+4(\mathrm{Q})+2 \mathrm{Na}^{+} \\
(\mathrm{C})+10 \mathrm{H}^{+} & \leftrightharpoons(\mathrm{K})+(\mathrm{Q})+5 \mathrm{Mg}^{++}+7 \mathrm{H}_{2} \mathrm{O} \\
6(\mathrm{Mm})+2 \mathrm{H}^{+}+7 \mathrm{H}_{2} \mathrm{O} & \leftrightharpoons 7(\mathrm{~K})+8(\mathrm{Q})+\mathrm{Mg}^{++}
\end{aligned}
$$

where the parenthesized $\mathrm{F}, \mathrm{M}, \mathrm{Q}, \mathrm{K}, \mathrm{Ab}, \mathrm{C}$, and $\mathrm{Mm}$ denote aduralia $\left(\mathrm{KAlSi}_{3} \mathrm{O}_{8}\right.$ ), muscovite $\left(\mathrm{KAl}_{3} \mathrm{Si}_{3} \mathrm{O}_{10}(\mathrm{OH})_{2}\right)$, quartz $\left(\mathrm{SiO}_{2}\right)$, kaolinite $\left(\mathrm{Al}_{2} \mathrm{Si}_{2} \mathrm{O}_{5}(\mathrm{OH})_{4}\right)$, albite $\left(\mathrm{NaAlSi}_{3}\right.$ $\left.\mathrm{O}_{8}\right)$, chlorite $\left(\mathrm{Mg}_{5} \mathrm{Al}_{2} \mathrm{Si}_{3} \mathrm{O}_{10}(\mathrm{OH})_{8}\right)$, and montmorillonite $\left(\mathrm{Mg}_{0.167} \mathrm{Al}_{2.33} \mathrm{Si}_{3.67} \mathrm{O}_{10}(\mathrm{OH})_{2}\right)$, respectively. The equilibrium constants for the above reactions are available below $300^{\circ} \mathrm{C}$. The equilibrium $\mathrm{pH}$ values for these reactions at a given temperature depend on activities of water and the related cations. Thus, when we deal with a system with 


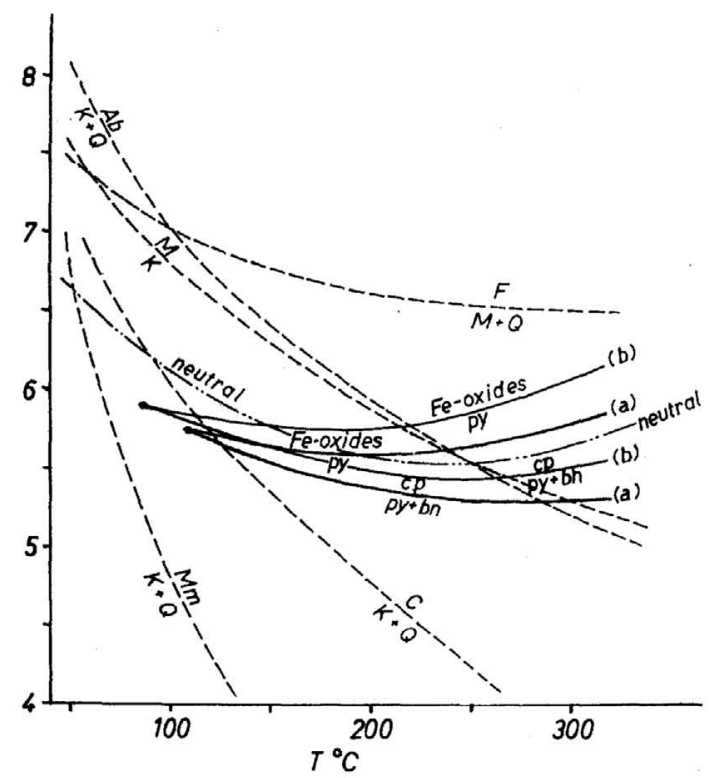

Fig.3. $\mathrm{pH}$ for the "black ore" deposition in the model system. Regions (a) and (b) correspond as to $\mathrm{fO}_{2}$ and $\mathrm{fS}_{2}$ conditions to those defined in Figs. 1 and 2.

the same cation concentrations as in the present-day oceanic water, it is possible to determine the temperature dependent $\mathrm{pH}$ values for the reactions at $1 \mathrm{~atm}$ confining pressure on the assumption that the activity of water is nearly equal to unity under the given conditions. The results are superposed on Fig.3. It is interesting to note that the inferred stable silicate minerals within the $\mathrm{pH}$ region of the ore deposition are consistent with the mineral assemblages in the Kuroko type deposits.

Under high confining pressures, the fugacity of water never remains constant. Therefore, the $\mathrm{pH}$ values defined in the foregoing would have to be corrected for this effect. However, assuming that only the activity of water depends on confining pressure, the $\mathrm{pH}$ region for the ore deposition shifts towards acid side by only about one unit even at $300^{\circ} \mathrm{C}$ and 1,000 bars.

(Examination of relative metallic abundances) The total molalities of zinc, iron, and copper in the solution are estimated on the basis of the data derived from the coprecipitation of barite and galena (curves "a" in Figs.1, 2, and 3). Calculations are performed on the basis of the following reactions, as in the previous paper (KAJIWARA, 1973):

$$
\mathrm{ZnS} \leftrightharpoons \mathrm{Zn}^{++}+\mathrm{S}^{--}
$$




$$
\begin{aligned}
2 \mathrm{FeS}_{2} & \leftrightharpoons 2 \mathrm{Fe}^{++}+2 \mathrm{~S}^{--}+\mathrm{S}_{2}, \\
4 \mathrm{CuFeS}_{2}+2 \mathrm{H}_{2} \mathrm{O} & \leftrightharpoons 4 \mathrm{Cu}^{+}+4 \mathrm{Fe}^{++}+8 \mathrm{~S}^{--}+4 \mathrm{H}^{+}+\mathrm{O}_{2} .
\end{aligned}
$$

The equilibrium constants for the reactions are available for temperatures below $300^{\circ} \mathrm{C}$ (HELgeson, 1969). The activity of $\mathrm{S}^{--}$can be given from the activity product of galena, since the present calculations are based on the coprecipitation of barite and galena. Stoichiometric activity coefficients for the related ionic species are known (Helgeson, 1969). Thus, assuming that the activity of water is nearly equal to unity, the total molalities of zinc, iron, and copper in the solution can be evaluated, and the results are shown in Figs.4a-4d. From the precondition of the present calculations the total molalities of barium and lead in the solution are exactly the same as those observed in the present-day oceanic water at any temperatures discussed. The relative abundances of barium, lead, zinc, copper, and iron in the solution are represented in Figs.5a-5d. The calculated total molality of sulfur in the system lies in the range from -1.7 to -0.9 in $\log$ unit, which is satisfactorily consistent with the value of the present-day oceanic water $(-1.6)$. One might say that the calculated molalities of the ore-forming metals are too far from the values observed in oceanic water to be regarded as "consistent". However, as is well known, the analytical data for these oceanic trace elements still contain significant uncertainties up to one or more in log unit and, further, the molalities of these elements in ocean water may fluctuate over the range of \pm 1 in $\log$ unit depending on the sampling location (e.g. MASON, 1958).

Thus, summarizing the results obtained here, it may be concluded that the model hydrothermal system with the same metallic abundances as in the present-day oceanic water can satisfactorily account for the mineralization of "black ore" of the Kuroko type deposits.

Yellow ore and siliceous ore Only pyrite and chalcopyrite are the essential sulfide constituents of "yellow ore" and "siliceous ore" in the Kuroko type mineralization. Therefore, the genetical condition of these ores in the model hydrothermal system is examined on the basis of the coprecipitation of these sulfide minerals.

Let us consider the equations (17) and (18) again. From these equations, we obtain equation (19) involving the coprecipitation of pyrite and chalcopyrite.

$$
4 \mathrm{FeS}_{2}+4 \mathrm{Cu}^{+}+4 \mathrm{~S}^{--}+4 \mathrm{H}^{+}+\mathrm{O}_{2} \leftrightharpoons 4 \mathrm{CuFeS}_{2}+2 \mathrm{H}_{2} \mathrm{O}+2 \mathrm{~S}_{2}
$$

The equilibrium constants for the above equations are available below $300^{\circ} \mathrm{C}$ (Helgeson, 1969). The activities of $\mathrm{Fe}^{++}$and $\mathrm{Cu}^{+}$are determined from the model this time. Thus, assuming that the activity of water is nearly equal to unity, the coprecipitation condition of pyrite and chalcopyrite in the model system can be evaluated as functions of oxygen fugacity, sulfur fugacity, and $\mathrm{pH}$ at any given temperature below $300^{\circ} \mathrm{C}$. Some examples of the results are shown in Fig.6. 


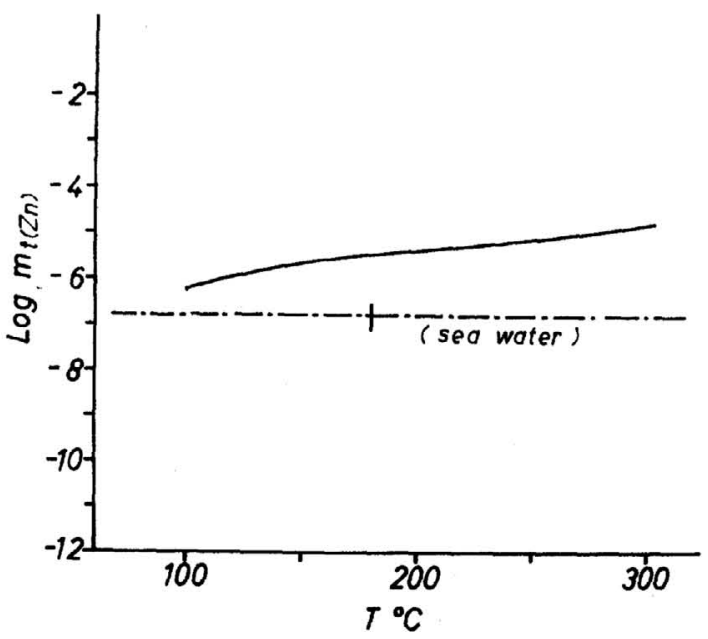

Fig.4a.

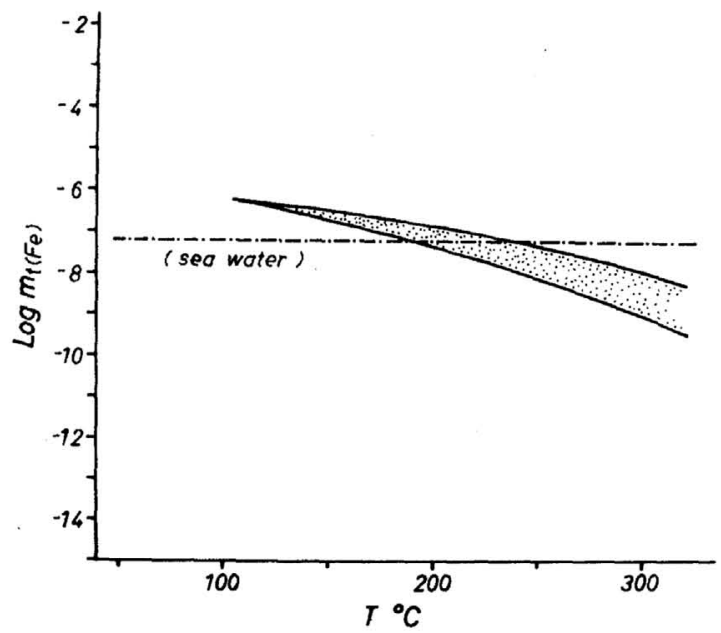

Fig.4b.

Figs. $4 \mathrm{a}, 4 \mathrm{~b}, 4 \mathrm{c}$, and $4 \mathrm{~d}$. Total molalities of zinc, iron, and copper in the solution in equilibrium with "black ore" under the $\mathrm{fO}_{2}, \mathrm{fS}_{2}$, and $\mathrm{pH}$ conditions defined from the coprecipitation of barite and galena (refer to curves "a" in Figs.1, 2, and 3). In Fig.4c, the total molality of iron varies as shown in Fig.4b. In Fig.4d, the total molality of iron is constant, being taken to be the seawater value. 


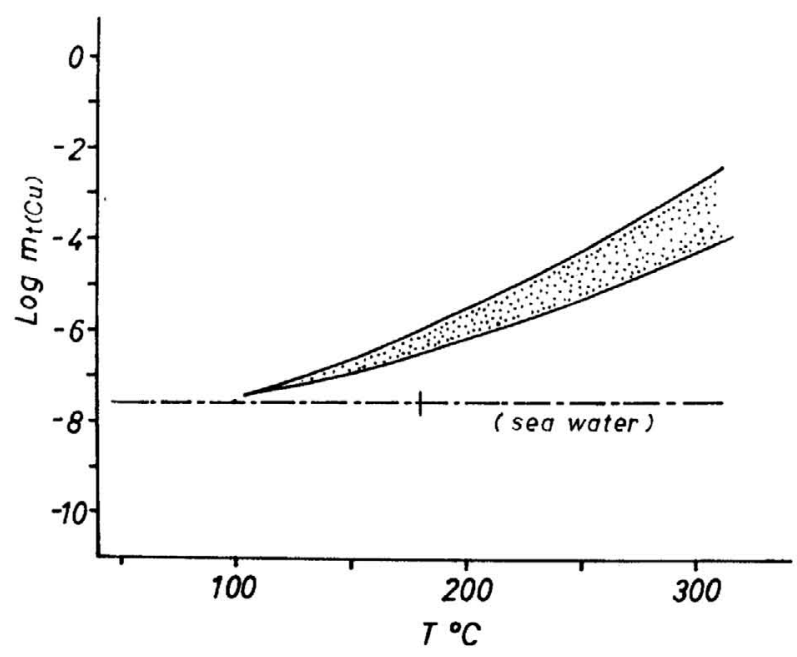

Fig.4c.

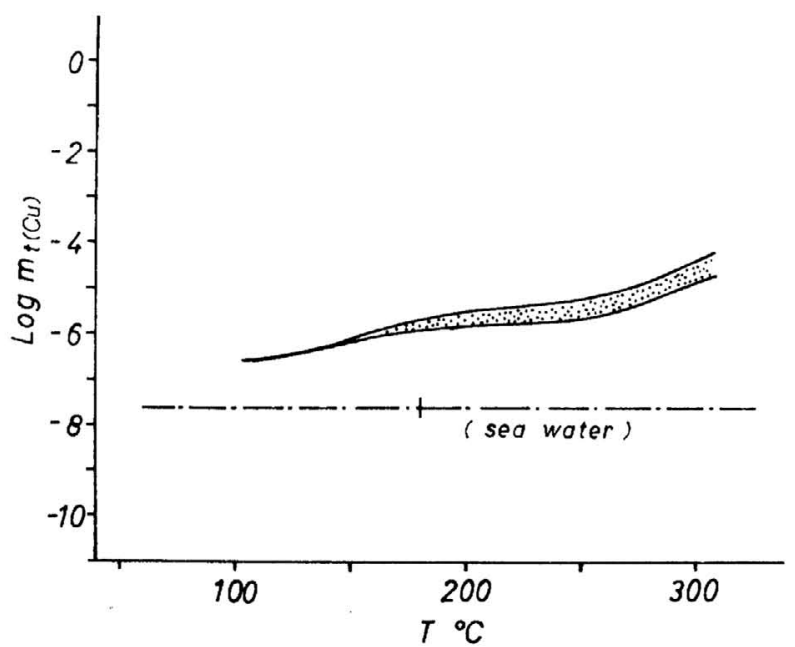

Fig.4d.

Gypsum ore Ca-sulfate mineral (gypsum and/or anhydrite) and pyrite are the essential constituents of "gypsum ore" in the Kuroko type mineralization. Therefore, the genetical condition for this type of ore in the model hydrothermal system is examined on the basis of the coprecipitation of these minerals:

$$
\begin{aligned}
4 \mathrm{FeS}_{2}+4 \mathrm{H}_{2} \mathrm{O} & \leftrightharpoons 4 \mathrm{Fe}^{++}+7 \mathrm{~S}^{--}+\mathrm{SO}_{4}^{--}+8 \mathrm{H}^{+}, \\
\mathrm{CaSO}_{4} & \leftrightharpoons \mathrm{Ca}^{++}+\mathrm{SO}_{4}^{--} .
\end{aligned}
$$




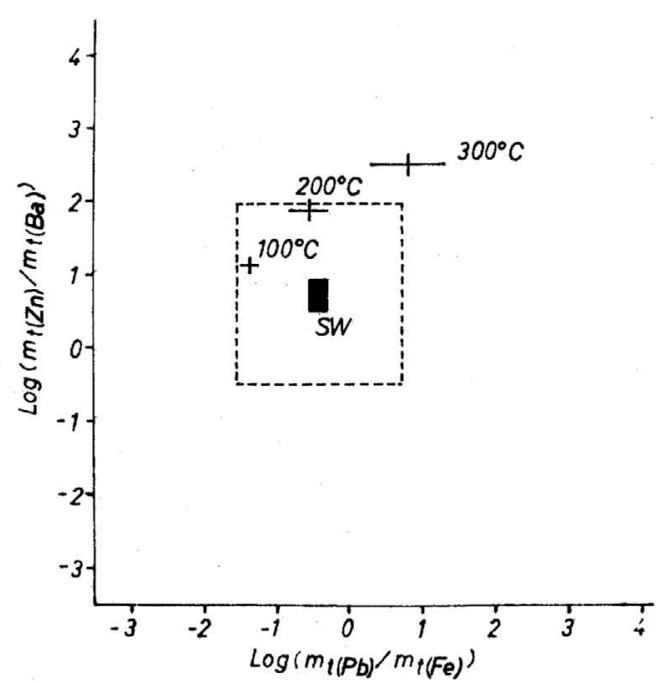

Fig.5a

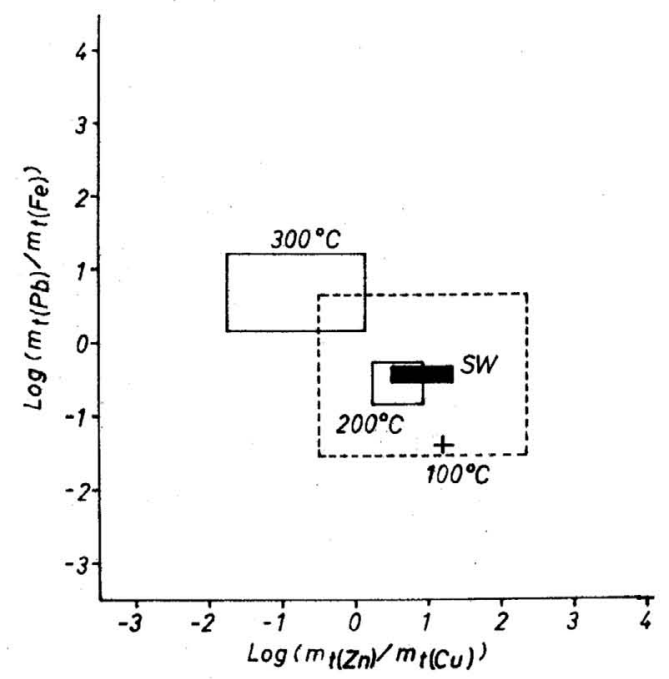

Fig.5b

Figs.5a, 5b, 5c, and 5d. Molality ratios involving barium, lead, zinc, iron, and copper in the model solution system defined from the coprecipitation of barite and galena. The values in the regions limited by dotted lines are within \pm 1 in $\log$ unit from the present-day ocean water values (SW). 


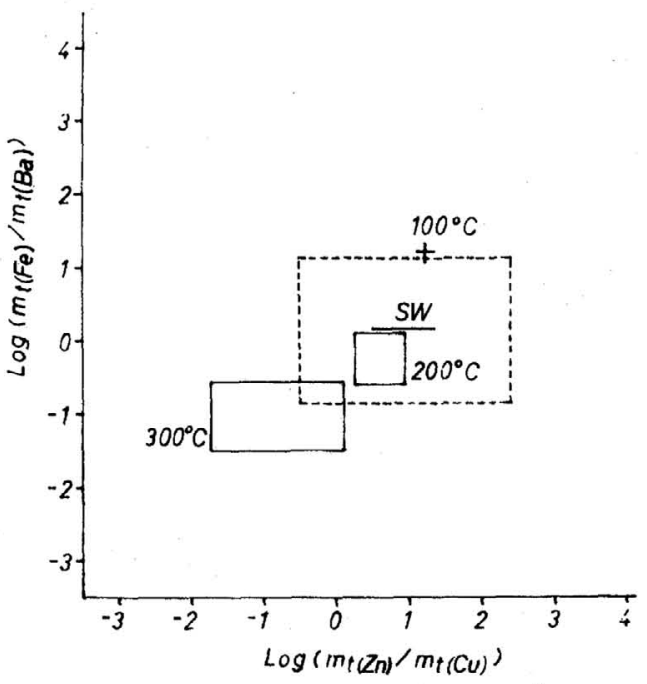

Fig.5c.

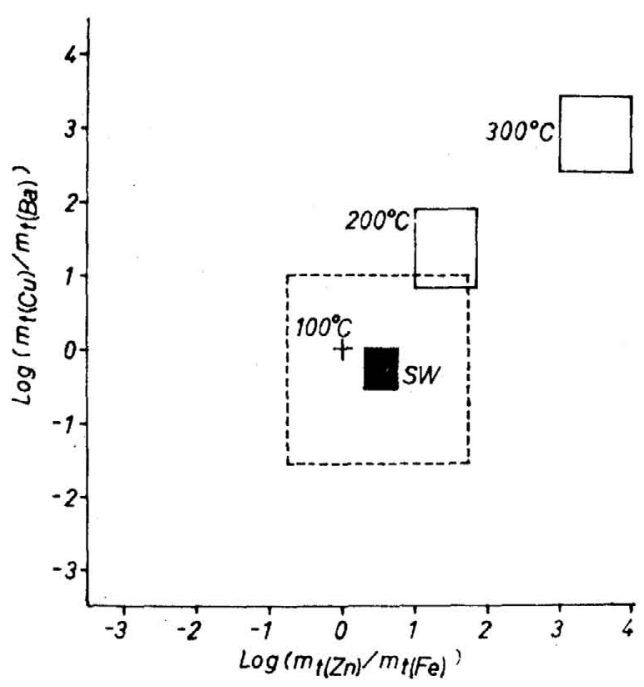

Fig.5d.

Thus, we obtain equation (22) for the coprecipitation of pyrite and anhydrite (anhydrite is stable above $57^{\circ} \mathrm{C}$ in pure water at $1 \mathrm{~atm}$ confining pressure, HARDIE, 1967):

$$
4 \mathrm{FeS}_{2}+\mathrm{Ca}^{++}+4 \mathrm{H}_{2} \mathrm{O} \leftrightharpoons \mathrm{CaSO}_{4}+4 \mathrm{Fe}^{++}+7 \mathrm{~S}^{--}+8 \mathrm{H}^{+} \text {. }
$$

Combining equation (22) with equation (2) which involves the oxidation-reduction reaction of ionic sulfur species, we obtain 


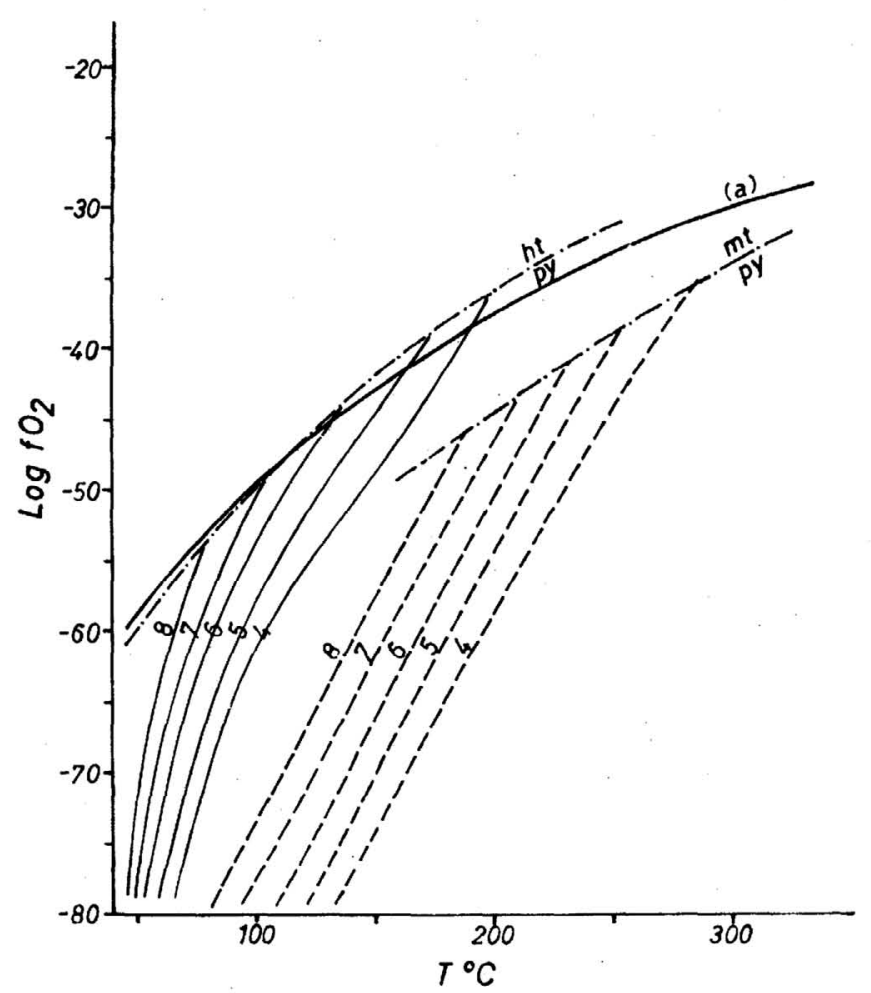

Fig.6. Coprecipitation condition of pyrite and chalcopyrite in the model system under $\mathrm{fS}_{2}$ buffered conditions. The $\mathrm{pH}$ dependence is represented by numbered contours. Solid lines are constructed under $\mathrm{fS}_{2}$ conditions as buffered by pyritechalcopyrite-bornite assemblage (upper stability limit of pyritechalcopyrite assemblage) and dashed lines under those as buffered by pyrite-pyrrhotite assemblage (lower stability limit of pyrite-chalcopyrite assemblage). For curve (a), refer to Fig.1.

$$
4 \mathrm{FeS}_{2}+4 \mathrm{H}_{2} \mathrm{O}+\mathrm{Ca}^{++}+14 \mathrm{O}_{2} \leftrightharpoons \mathrm{CaSO}_{4}+4 \mathrm{Fe}^{++}+7 \mathrm{SO}_{4}^{--}+8 \mathrm{H}^{+}
$$

The equilibrium constants for the above reactions are available below $300^{\circ} \mathrm{C}$ (HELGESON, 1969). The activities of $\mathrm{Ca}^{++}$and $\mathrm{Fe}^{++}$are given from the model. The activity of $\mathrm{SO}_{4}^{--}$ is determined from the activity product of anhydrite. Thus, assuming that the activity of water is nearly equal to unity, the coprecipitation condition of pyrite and anhydrite in the model system as functions of oxygen fugacity and $\mathrm{pH}$ at temperatures below $300^{\circ} \mathrm{C}$ can be estimated (Fig.7). 


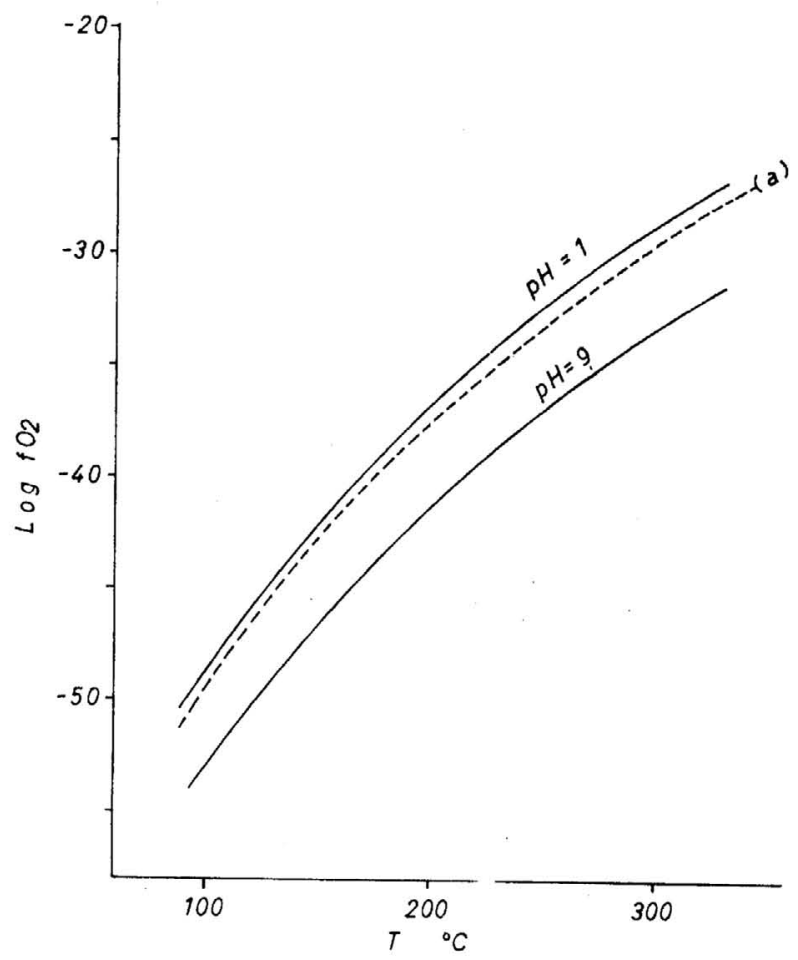

Fig.7. Coprecipitation condition of anhydrite and pyrite in the model system. Dotted curve (a): The $\mathrm{fO}_{2}$ condition for the coprecipitation of barite-galena as defined in Fig.1.

genetical conditions of Kuroko ores estimated by the present model. The data are illustrated in two isothermal $\mathrm{pH}-\mathrm{fO}_{2}$ diagrams constructed at $200^{\circ}$ and $250^{\circ} \mathrm{C}$, respectively. It is seen that the $\mathrm{pH}-\mathrm{fO}_{2}$ condition for "black ore" deposition (as defined essentially from the coprecipitation of barite and galena or sphalerite) is situated in the field in which oxidized ionic sulfur species are predominant and those for "yellow ore" and "siliceous ore" (as defined from the coprecipitation of pyrite and chalcopyrite) in the relatively low $\mathrm{fO}_{2}$ and/or $\mathrm{pH}$ field, though it depends largely on sulfur fugacity. It is also found that the $\mathrm{pH}-\mathrm{fO}_{2}$ condition responsible for the deposition of "gypsum ore" (anhydrite-pyrite ore) is in the proximity of the field boundary between hydrogen sulfide and oxidized sulfur species. Field observations indicate that ores in the Kuroko type deposits are stratified to form in general "gypsum ore", "yellow ore", and "black ore" layers in the ascending order (refer to "Volcanism and ore genesis" edited by T. TATSUMI, 1970). Thus, on the basis of the present model, the ore zoning observed in this type of mineralization is most likely due to the oxidation and/or neutralization processes during the course of mineralization, if the temperature of ore 


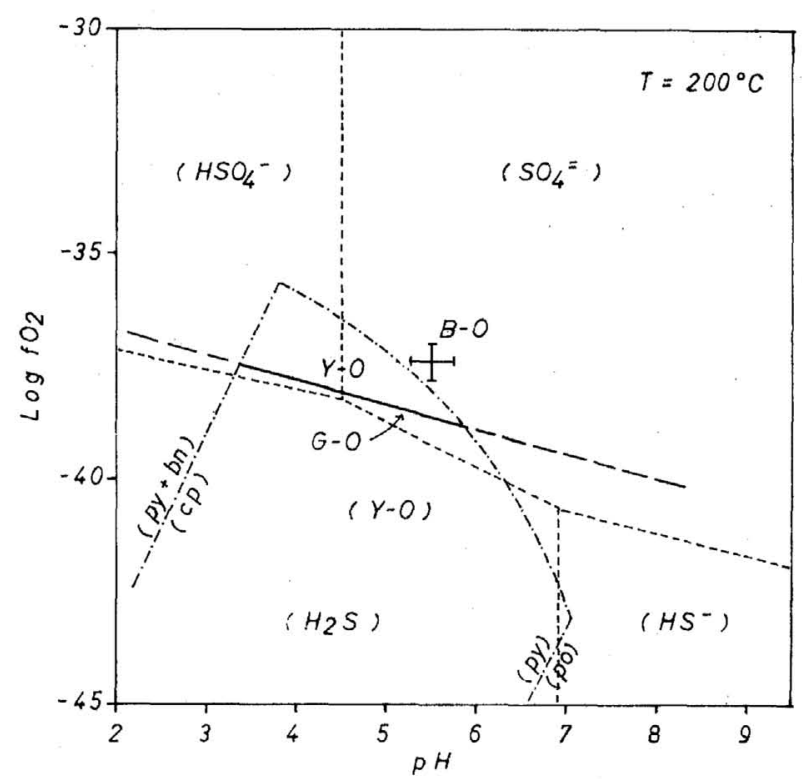

Fig.8a.

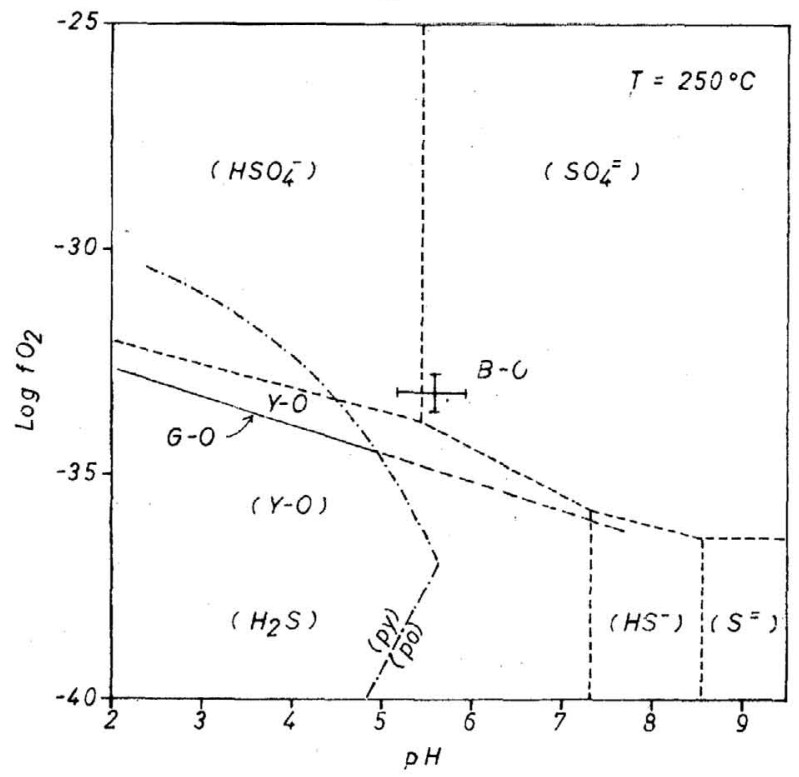

Fig.8b.

Figs.8a and $8 \mathrm{~b}$. Isothermal $\mathrm{pH}-\mathrm{fO}_{2}$ diagrams showing the genetical conditions of "black ore" (B-O), "yellow ore" $(\mathrm{Y}-\mathrm{O})$, and "gypsum ore" (G-O) in the model system. (Note: Pyrite and chalcopyrite can be coprecipitated under condition within the fields limited by dash-dot lines depending on sulfur fugacity.) 
deposition does not vary remarkably throughout all the stages of the mineralization. This is in agreement with the interpretation expressed in sulfur isotope studies on this type of mineralization (Оhмото et al., 1970; KAJIWARA, 1971; KAJIWARA and DATE, 1971).

\section{CONCLUSION}

We have observed that the model hydrothermal system characterized by the same metallic abundances as in the present-day oceanic water can explain satisfactorily the observed mineralogical and geochemical features of the Kuroko deposits.

If the present hypothesis is accepted, it appears probable that many of the natural hydrothermal systems represent the circulating seawaters incorporated into the earth's crust during the processes of orogeny. With this view, the natural hydrothermal mineralization may be classified roughly into two types as illustrated in Fig.9, i.e.,

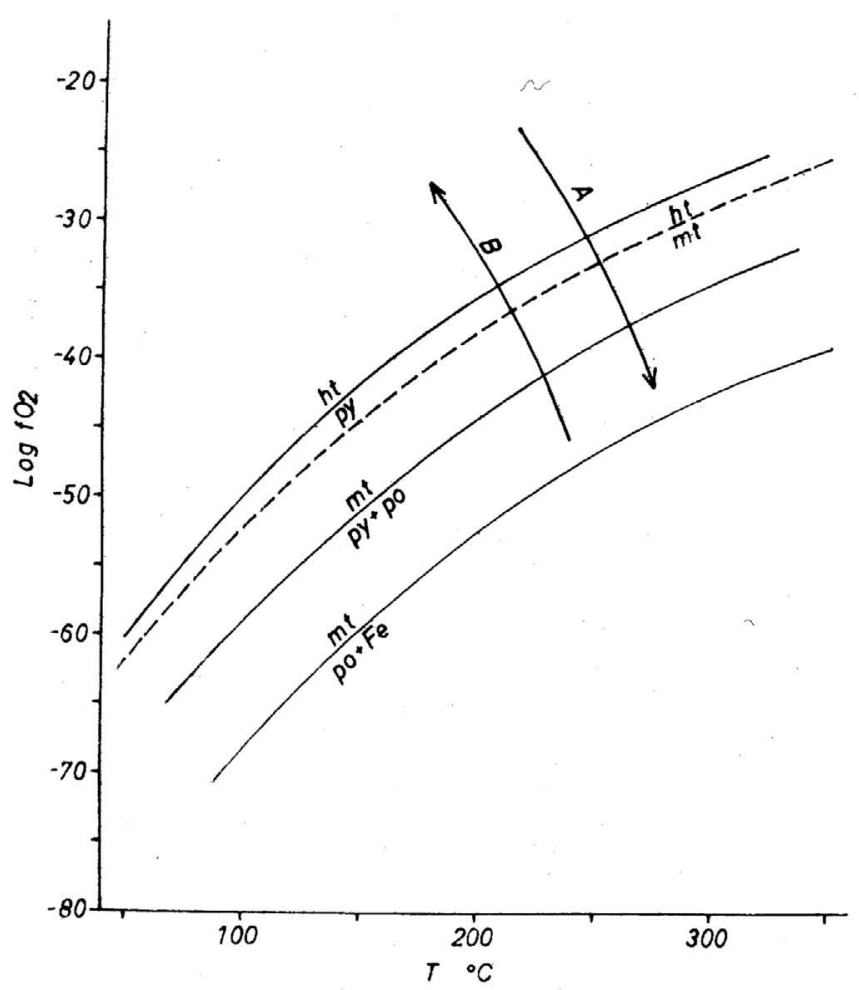

Fig.9. Possible two types of mineralization during cyclic or recyclic processes of seawater in the earth's crust. (Note: The pyrite-hematite curve is constructed under $\mathrm{fS}_{2}$ conditions as buffered by pyrite-chalcopyrite-bornite assemblage.) 
(A) mineralizations due to the reduction processes of the circulating seawater and (B) those due to the re-oxidation processes of the once reduced circulating seawater. As seen from the diagram, the most convenient criterion in discriminating these two types in nature may be the mode of ore-zoning involving iron sulfides and oxides. The deposits formed in shallow environments such as Kuroko and those formed in relatively deep environments such as contact metasomatic deposits may represent the oxidation- and the reduction-type mineralization, respectively.

The availability of such circulating seawaters in the earth's crust and possibly in some parts of the upper mantle might also be essential in the generation of silicate magmas in orogenic belts.

This would have an important bearing on the problem of the evolution of hydrosphere and atmosphere of the earth (e.g., RuBEY, 1951; Holland, 1962, 1965; Kramer, 1965; ShImAZU and U'rabe, 1967; MATSUO, 1969, 1970).

\section{ACKNOWLEDGMENTS}

I wish to thank Drs. T. SATO and A. SASAKI (Geological Survey of Japan), T. TATSUMI, T. FUJII, and E. HORIKOSHI (University of Tokyo), H. OHMOTO (Pennsylvania State University), and S. MATSUO (Tokyo Institute of Technology) for the benefits of stimulating discussions of the problems involved. Special thanks are due to Dr. T. MrYAzAwa (Tokyo Kyoiku University) for discussion and encouragement during the course of this study.

\section{REFERENCES}

HARDIE, L. A. (1967) Gypsum-anhydrite equilibrium at one atmosphere pressure. Am. Mineral. 52, 171-200.

HELGeSON, H. C. (1969) Thermodynamics of hydrothermal systems at elevated temperatures and pressures., Am. J. Sci. 267, 729-804.

HollaNd, H. D. (1962) Model for the evolution of the earth's atmosphere, in Petrologic studies ed. Geol. Soc. Am. 447-477.

HollaND, H. D. (1965) The history of ocean water and its effect on the chemistry of the atmosphere. Proc. Nat. Acad. Sci. 53, 1173-1183.

KAJIWARA, Y. (1971) Sulfur isotope study of the Kuroko ores of the Shakanai No.1 deposits, Akita Prefecture, Japan. Geochem. J. 4, 157-181.

KAJIWARA, Y. and DATE, J. (1971) Sulfur isotope study of Kuroko type and Kieslager type strata-bound massive sulfide deposits in Japan. ibid. 5, 133-150.

KAJIWARA, Y. and HoNma, H. (1972) Lead content in barite coexisting with galena-An indicator of oxygen fugacity during ore deposition. Mining Geol. (Tokyo), 22, 457-465.

KAJIWARA, Y. (1973) Chemical composition of ore-forming solution responsible for the Kuroko type mineralization in Japan. Geochem. J. 6, 141-149.

KRAMER, J. R. (1965) Hisotry of seawater: Constant temperature-pressure equilibrium models compared to liquid inclusion analyses. Geochim. Cosmochim. Acta 29, 921-945.

MASON, B. (1958) Principles of geochemistry, 2nd ed., John Wiley \& Sons Inc., New York.

MATSUO, S. (1969) Origin and evolution of the earth's atmosphere: Kagaku-no-Ryoiki (Fields of Chemistry) 23, 345-351 (in Japanese). 
Matsuo, S. (1970) Origin of surface waters of the earth. Kaiyokagaku-kisokoza (Basic lectures on oceanic sciences) 10, 82-112, Tokai Univ. Press (in Japanese).

OHmoto, H., KaJiwarA, Y., and DATE, J. (1970) The Kuroko ores in Japan: Products of seawater?, Ann. Mtgs. Geol. Soc. Am., (Milwaukee,'70), Abstract, 640.

RUBEY, W. W. (1951) Geologic history of seawater: An attempt to state the problem. Bull. Geol. Soc. Am. 62, 1111-1147.

ShimazU, Y. and URABE, T. (1967) Some numerical experiments on the evolution of the terrestrial atmosphere and hydrosphere. J. Phys. Earth 15, 1-18.

TATSUMI, T. (1970) Volcanism and ore genesis. Univ. Tokyo Press.

\section{ADDENDUM}

All the calculations in the present paper were based on the data compiled by MASON(1958). However, as regards the dissolved trace elements in the oceanic water, the data are not satisfactorily consistent with those compiled more recently by GoLDBERG (1965). Therefore, the author has reexamined all the calculations in the text on the basis of the latter data. The results reveal that the curves (a) in Figs.1, 2, and 3 shift towards the curves (b) in the same diagrams to become nearly identical with each other, and that the metallic abundances in the solution responsible for the deposition of "black ore" (Figs.5a-5d and 6a-6d) become more consistent with the seawater values.

\section{REFERENCE}

GoldberG, E. G. (1965) Chemical oceanography ed. by J. P. RILEY and G. SkIRrow, Vol.1, 164-165. Academic Press Inc., New York. 